\title{
THE HAUSA PERFECTIVE TENSE-ASPECT USED IN WH-/FOCUS CONSTRUCTIONS AND HISTORICAL NARRATIVES: A UNIFIED ACCOUNT
}

\author{
Philip J. Jaggar
}

\section{Introduction*}

Russell Schuh has always been attracted to the linguistic study of tense, aspect and mood categories in various genres of Hausa discourse. In the early 1980s he wrote up an insightful paper entitled "Hausa tense/aspect/mood (TAM) system" (Schuh, n.d.a), mainly for the benefit of UCLA students (of which I was one at the time). Around the same period, he also produced a paper dealing more specifically with the two Perfective tense-aspects in Hausa (Schuh, n.d.b). We were aware that the Hausa TAM system was poorly understood and would benefit by detailed and robust examination, and so I wrote a paper entitled "The two perfective aspects and their roles in the flow-control of narrative structures" (1981) as part of my graduate linguistics training, although I did not follow up on that line of research.

In this paper I want to revisit and elaborate some of the ideas I outlined in the earlier paper, concentrating on the semantic characteristics of the paired Perfective tense-aspects in a major discourse context-spontaneously-produced past-time narrative. The main focus is on the role of the paradigm known traditionally as the "Relative Perfective", a set that is in partial complementary distribution with the "General/Neutral Perfective". This tense-aspect form is the one exploited at discourse-level to assert prominent events on the time-axis in foregrounded narrative sequences, but it is also required in classic clause-level wh-constructions, i.e., wh-

\footnotetext{
" My thanks to Sani Ahmad Sufi who provided the oral narratives. I have exchanged ideas and data with Katharina Hartmann, who has been independently investigating Hausa focus and narrative discourse, see Hartmann (in press) and Hartmann \& Zimmermann (in press).
} 
interrogatives, declarative focus constructions, and relative clauses, operations which often share structural properties across languages. (The corresponding "Relative Imperfective" is also obligatory in these movement operations but is not required in narrative, because past-time historical narrative event-lines are carried by the "Relative Perfective".) Formal descriptions, e.g., Tuller (1986) and Green \& Reintges (2005), essentially treat the two Perfectives as syntactically-conditioned variants of the same semantic unit, i.e., the assumption is that there is no specifiable (or interesting) correlation between the morphosyntactic signal and the meanings/functions of these variants. But the obvious question to be asked is: assuming that we are dealing with a single aspectual category here, what semantic properties do all these constructions share which account for their shared morphosyntactic properties and so explain why they constitute a natural class? I suspect that one reason this form-function question has not been properly addressed relates to the fact that, unlike foreground narrative clauses, wh-/focus/relative constructions all entail visible movement and so the various phenomena do not obviously fall together structurally.

Partly in response to earlier formal approaches, which leave various contrasts unexplained, both Schuh and myself have argued (and intuitively felt) for some time that the so-called "Relative Perfective" set is not simply a syntactically-governed replacement for the "General/Neutral Perfective" in fronting operations, but has a distinct semantic property which unifies all these related constructions with its role as the marker of narrative event-clauses, i.e., we are dealing with a single morphological and functional entity. Schuh (n.d.a) characterizes the superordinate semantic attribute as "definite" and the tense-aspect itself as the "Definite Perfective", but I prefer the cover-terms "prominence" and "Focus Perfective" for reasons outlined below $(\$ 3.3)$.

I am aware that "prominence" is an intuitive notion which is difficult to define in a totally satisfactory manner, but I hope to refine and validate this concept by pulling together a large body of evidence for the underlying semantic-pragmatic unity of these constructions. I also take a look at the TAMs which occur in background clauses, especially the General Perfective, examining how discourse-semantic constraints either restrict or favour the switch between the two Perfective sets. The corpus I am using consists of two naturally-produced oral narratives: a "brush-withdeath" account and a Pear Film story-retelling task, see Chafe (1980). (For other discourse analyses of Hausa narratives, see Burquest (1991).)

My central claim is that the fronted focus/wh-constructions and pivotal foregrounded portions of past-time narratives utilize the same specialized Perfective tense-aspect morphology because they achieve the same discourse-pragmatic 
goals - they all supply the most communicatively prominent and focal new information. At sentence-level, i.e., in focus constructions and interrogatives, it is typically an NP constituent (any syntactic function) which is given prominence via focus-fronting, and this will represent new information focus in response to a whquestion (and often in corrective focus); at discourse-level in foreground narrative, it is typically the verbal predicate which is highlighted as the pivotal new information, and the syntactic (topical) subject is presupposed, addressee-old information (though this is not an absolute requirement, since new subjects can be introduced in foreground). Verbal predicates, or alternatively verbs as heads of their VPs, correspond to the semantic predicate, and because they fill the central role of laying out individual narrative events they are logical recipients for focus marking (Hopper 1979). All these constructions, moreover, involve grammaticalized foregrounding or highlighting/focussing of an addressee-new element as the most informative element in the clause. (Relative clauses do not always manifest these co-varying features but they do share important semantic and syntactic attributes with focus/wh- and narrative sequences.) The hypothesis is supported by an empirical study of contexts in which the two Perfective paradigms align with both syntactic and semanticpragmatic properties.

\section{An Overview of the Hausa TAM System}

Hausa is a discourse-configurational, pro-drop, SVO language in which TAM distinctions are marked by an obligatory inflectional element to the right of the

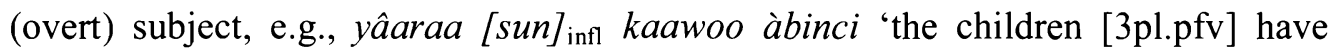
brought the food'. 'This independent preverbal word contains a subject-agreement element (marking person, number and gender) and an auxiliary TAM-marker, and is known as the "person-aspect complex" (PAC) (Newman 2000; Jaggar 2001). Some of these inflectional heads are fusional, e.g., sun (3pl.pfv), others are segmentable, e.g., su-nàa ( $3 \mathrm{pl}$ subject pronoun-impfv auxiliary). West Chadic languages typically present a basic three-way TAM system which distinguishes "Perfective",

\footnotetext{
${ }^{1}$ Transcription: $\grave{a}(a)=$ Low tone, $\hat{a}(a)=$ Falling tone, High tone is unmarked; $a a$, $i i$, etc. $=$ long, $a$, $i$, etc. $=\operatorname{short} ; \delta, d=$ laryngeal implosives, $k=$ ejective, $\tilde{r}=$ apical tap $/$ roll, $c$ and $j=$ palato-alveolar affricates. Abbreviations: $\mathrm{COP}=($ NON-VERBAL) COPULA; $\mathrm{DD}=$ definite determiner; $\mathrm{EXIST}=$ existential; $F=$ feminine; FOC-IMPFV = focus (relative) imperfective; FOC-PFV = focus (relative) perfective; FUT = future; $\mathrm{IMPFV}=$ imperfective; i.o. = indirect object; $\mathrm{M}=$ masculine; NARR-PFV = narrative perfective; $\mathrm{NEG}=$ negative; $\mathrm{PFV}=$ (general) perfective; $\mathrm{PL}=$ plural; $\mathrm{PRESENT}=$ presentative; $R E L P R O=$ relative pronoun; $S G=$ singular; $S I D=$ specific indefinite marker; $S J N C T V=$ subjunctive; SUBORD = subordinator; $\mathrm{VN}=$ verbal noun; $1 / 2 / 3 / 4=\mathrm{first} / \mathrm{second} /$ third/fourth person.
} 
"Imperfective", and "Subjunctive" (Schuh 1977). The meanings of the two tenseaspect verbal paradigms correspond closely to the standard semantic definitions of perfective and imperfective aspectuality, i.e., the perspective adopted by the speaker in viewing the event - the Perfective describes situations in their entirety from the outside, whereas the Imperfective refers to the internal temporal structure (Comrie 1976). The basic syntactic cut in Hausa is between the Imperfective/Continuous forms (e.g., with non-finite VPs, possessive and adverbial complements), and Perfective/Completive TAMs (governing finite verbs), e.g.,

(1)

English

a. Tense: [non-past] [past]

'he studies

PRESENT 'he studied Hausa'

PAST

'he has studied Hausa'

PERFECT

b. Aspect:
Hausa

$=$ yanàa kòoyon Hausa

3msg.impfv study.vn.of Hausa

IMPERFECTIVE

$=$ yaa kòoyi Hausa

3msg.pfv study Hausa

PERFECTIVE

\section{'he is studying Hausa' = yanàa kòoyon Hausa PROGRESSIVE PRESENT IMPERFECTIVE 'he was studying Hausa' = yanàa kòoyon Hausa Progressive Past IMPERFECTIVE}

In (1a) English makes a formal tense distinction between non-past (Present Tense) and past time (Past Tense/Preterite), with Hausa using an Imperfective and Perfective tense-aspect respectively, locating the situation at a specific point in time (usually the moment of speaking). The Hausa (General) Perfective also encompasses both the Simple Past and Perfect in English, depending on context. In (1b), the formal switch in English from (Progressive Present) 'he is studying Hausa' to (Progressive Past) 'he was studying Hausa' is an obligatory reflex of the change from present to past-time reference, but Hausa expresses both meanings with the same Imperfective form (relying on context or an overt temporal adverbial to locate the event in time). The Imperfective views the situation from the inside, and the basic meaning is linked to "the internal temporal consistency of the situation" (Comrie 1976:4). Hausa can also use the non-completed Imperfective to encode both aspectual non-progressive 'he smokes' and progressive ongoing 'he is smoking' (situation coextensive with utterance), i.e., yanàa shân taabàa (3msg.impfv drink.vn.of tobacco). 


\section{The Perfective and Focus (inc. Narrative) Perfective Tense-Aspects}

\subsection{Forms}

Hausa has two formally distinct affirmative Perfective paradigms, and one negative set (which functions as the negative to both). In the affirmative conjugations, Hausa displays a paradigmatic morphological cut between "General" and what I will term "Focus" inflection. All three sets are exemplified in Table 1 with the finite verb daawoo 'return':

Table 1. Hausa General Perfective, Focus Perfective, and Negative Perfective TAMs

\begin{tabular}{|l|l|l|l|}
\hline & General Perfective & Focus Perfective & Negative Perfective \\
\hline $1 \mathrm{sg}$ & naa daawoo & na daawoo & bàn daawoo ba \\
\hline $2 \mathrm{msg}$ & kaa daawoo & ka daawoo & bà kà daawoo ba \\
\hline $2 \mathrm{fsg}$ & kin daawoo & kikà daawoo & bà kì daawoo ba \\
\hline $3 \mathrm{msg}$ & yaa daawoo & ya daawoo & bài daawoo ba \\
\hline $3 \mathrm{fsg}$ & taa daawoo & ta daawoo & bà tà daawoo ba \\
\hline $1 \mathrm{pl}$ & mun daawoo & mukà daawoo & bà mù daawoo ba \\
\hline $2 \mathrm{pl}$ & kun daawoo & kukà daawoo & bà kù daawoo ba \\
\hline $3 \mathrm{pl}$ & sun daawoo & sukà daawoo & bà sù daawoo ba \\
\hline $4 \mathrm{pl}$ & an daawoo & akà daawoo & bà à daawoo ba \\
\hline
\end{tabular}

From a West Chadic perspective, Hausa is unusual in distinguishing two paired Perfective paradigms (Schuh, n.d.c:10), though Kanakuru does exhibit the same pattern (Newman 1974:65ff.). Newman \& Schuh (1974:7) claim that the $k a$ is a reflex of a proto-Chadic perfective marker ${ }^{*} k a ̀$ or $* k \grave{\partial}$, though Schuh (n.d.c:11) now relates this morpheme to a copular element derived from a ${ }^{*} k V$ deictic determiner (see also Jaggar 2001:205). The Focus/Narrative Perfective paradigm was the historically original set which became restricted to focus environments (including predicate "focus" in historical narrative, §6.1), when the new General Perfective was introduced. The General Perfective itself was originally a non-bound independent paradigm which was reworked as a preverbal subject pronoun set (Newman \& Schuh 1974).

\subsection{Basic Functions and Meanings of the Two Affirmative Perfective TAMs}

The two affirmative Perfective tense-aspects are the main concern of this paper. Semantically they both express the temporal notion of anteriority, i.e., they locate a situation at a time preceding the time-orientation expressed by other elements in the 
sentence (or speech context). To account for these (and other) temporal relationships between past, present and future time, and following Declerck (1986, 1991), I will use the following three concepts. (I have taken the liberty of simplifying her model for purposes of this discussion.)

a. The "time of orientation" (TO) = usually the time of speaking (or writing)

b. The "time referred to" (TR) = past time, present time, future time

c. The "time of situation" (TS) = locating the situation in time (perfective and imperfective aspectuality)

In the default case, the core function of both Perfectives is to express the past-time relation [TR is anterior to $(<)$ TO], i.e., where TO is the moment of speaking, e.g., (TAM markers and verbs underlined):

(2) taa hàifi daa namijì

3 fsg.pfv give birth to son male

[Gen. Perfective $=$ past time $]$

'she gave birth to a boy'

(3) suu nèe sukà zoo

[Focus Perfective $=$ past time]

3 pl cop 3pl.foc-pfv come

'they were the ones (they) came'

When we look at the General Perfective, however, the association between form and past-time reference is not a neat one-to-one match. Because perfective aspectuality expresses situations and events as complete wholes which are not time-related (Comrie 1976, 1985), past-time reference is not a necessary condition for selection of the General Perfective. It can be used, for example, in contexts which do not refer to the moment of speaking ( $\$ 5.2 .4$ ), and can be regarded as the pragmatically neutral, unmarked form of the paired set. (It is also the form compatible with canonical declarative clauses, $§ 5.2 .1$.) Thus, a future construal of the default General Perfective is found in subordinate conditional clauses, where it indicates that the reference time is posterior $(>)$ to the orientation time, i.e., TR $>$ TO, e.g.,

(4) koo kin zoo gòobe, bàa zaa kì sàamee sù ba [Gen. Perf. = future time] even if 2 fsg.pfv come tomorrow neg fut $2 \mathrm{fsg}$ find $3 \mathrm{pl} \mathrm{neg}$ 'even if you come [have come] tomorrow, you won't find them'

In contrast, the affirmative Focus/Narrative Perfective is deictic in the sense that it is almost always interpreted in relation to the time of the utterance and in its primary use is restricted to expressing bounded single-occurrence events and situations 
which are anterior to the utterance-time only (with the marginal exception of open if-conditional clauses, §5.2.4), i.e., the relationship must be TR $<$ TO. The Focus form of the Perfective is therefore much closer to being a tense. Interestingly, if Schuh (n.d.c:11) is correct in identifying the Focus Perfective kà morpheme as a copular ${ }^{*} k V$ element derived from a deictic determiner, then we have a possible diachronic match in spatiotemporal deictic function.

\subsection{Previous Descriptions and Definitions of the Two Perfectives}

There are probably as many terms for the two paradigm sets in the literature as there are Hausaists who have described them, some based on semantic attributes and others on the grammatical properties, e.g., "Past Indicative/Relative Past" (Abraham 1959); "Perfect/Aorist" (Parsons 1960); "Accompli I/Accompli II" (Gouffé 1963/66, Caron 1991); "General Past/Relative Past" (Galadanci 1976); "Absolute Past/Relative Past" (Jungraithmayr \& Munkaila 1985); "Completive/Relative Completive" (Burquest 1992); "Perfekt/Relative Perfekt (Historicus)" (Wolff 1993); "Completive/Preterite (Relative Completive)" (Newman 2000); "General/Focus Perfective" (Jaggar 2001); "General/Relative Completive" (Schuh, n.d.c).

The set I refer to here as the "Focus/Narrative Perfective" is probably best known to Hausaists as the "Relative Perfective" (because of its occurrence in relative clauses), and most descriptions analyze it simply as a syntactically-determined (obligatory) replacement for the "General Perfective" in focus, wh-, and relative constructions. Most treatments, however, ignore its key narrative-tracking function. Bagari (1987: chap. 4) and Schubert (1971/72:270-73) discuss environments where the two sets contrast in meaning, e.g., in subordinate clauses, but neither proposes a uniform compositional meaning which would generalize to all occurrences, i.e., including narrative sequences.

Schuh (n.d.a), responding to a term ("Relative Perfective") he considered narrow and misleading, proposed a semantic/pragmatic characterization. He used the label "Definite Perfective" to capture the semantic generalization that it "represents events understood as specific to a time and/or place and already instantiated" (p. 14). Following Bagari (1976, 1987: chap. 4), he also claimed that in wh-/focus/relative environments the event is pragmatically "presupposed" in the sense that it "is taken as given by speaker and hearer" (see also Creissels 1991). This definition is on the right track, but close examination reveals some weaknesses. In the first place, if we look at how linguists such as Quirk et al. (1985:183ff.) appeal to the semantic notion of "definiteness" to explain the distribution of the simple Past Tense in English, it turns out that almost all the past-time contexts they exemplify would in fact require a General Perfective in Hausa, not a "Definite Perfective". Another drawback relates 
to the fact that although pragmatic presupposition does represent information which is "given", "taken for granted", "old", etc., the standard view of presupposed information is that it is "backgrounded" as "something that is not currently at issue" (Huddleston \& Pullum 2002:41-42, 1007ff., 1414ff.). The problem is that the Hausa "Definite Perfective" is normally used to highlight and assert elements which are "foregrounded" as informationally prominent and addressee-new, i.e., fronted focus and wh-constituents and foregrounded past-time narrative events, not "backgrounded" information which is not at issue (see also Bearth 1993:92).

In Jaggar (1998, 2001:161ff.), I adopted the term "focus" for the special inflectional categories of the Perfective (and Imperfective) tense-aspects used in wh/focus/relative environments, and appealed to the superordinate notion "semantic specificity" to explain its distribution in these environments in addition to narrative discourse. The criterion "specific" is certainly applicable in some cases, but it fails to provide necessary and sufficient conditions for the occurrence of the Focus Perfective. On the other hand, the cover-term "prominent" is preferable because it has a more general information-packaging range (especially as regards the syntactically associated movement constructions). Whatever the merits of these earlier attempts by Schuh and myself at a unified semantic characterization, they reflect our shared view that the alternation between the two Perfective tense-aspects is not simply a matter of syntactic conditioning, but that the selection of one or the other is also motivated by semantic and pragmatic factors.

\section{The Hypothesis}

My core claim is that the use of the "Focus Perfective" in fronted focus/whconstructions and the pivotal foregrounded portions of past-time narratives is a function of the fact that they all supply the most communicatively PROMINENT and focal NEW information and so achieve the same discourse-pragmatic goals. This is the key semantic/pragmatic link without which these distinct constructions have only an arbitrary relationship and appear to be functionally dissimilar. The psychological focus of attention is therefore syntactically signalled by the special focus tenseaspect. In focus/wh-constructions at the level of sentence grammar, it morphologically flags preposed focal elements, typically NP constituents which are given prominence via fronting, and this will represent unpredictable, addressee-new information focus in response to a wh-question. In foreground narrative, as pointed out by Hopper (1979), it is the chains of discrete events expressed in verbal predicates which are most frequently highlighted by special TAMs (such as the Focus/Narrative Perfective in Hausa) as the pivotal new intersentential information, 
and the syntactic subject (topic) is typically presupposed and addressee-old information. ${ }^{2}$ All these related constructions, moreover-focus/wh- and event-line predicate focus - involve foregrounding or highlighting of an unpredictable element as the most informative element in the clause —cf. Dorfman's (1969:5) reference to "central or core incidents, whose function is to serve as the central focus [my italics] or core of the larger episode..." (cited in Hopper \& Thompson 1980:281). Grounding, therefore, is a function of speaker choices at sentence-level and also across discourse. Relative clauses are more problematical in that they do not always manifest these co-varying properties, but they do share one important semantic feature with focus/wh- and narrative event-clauses - the use of the Focus Perfective serves to restrict and so highlight the denotation of the fronted head nominal modified by the relative clause.

For the specific purposes of this paper, I will continue to use the term "Focus Perfective" when referring to the occurrence of this TAM in clause-level focus/wh/relative environments, but will switch to "Narrative Perfective" when discussing its intersentential narrative-tracking role, with the understanding that this narrative function is simply a related discourse-level manifestation of the semantic content inherent in the Focus Perfective.

In order to validate the hypothesis, I bring together supportive evidence based on distinctive grammatical characteristics and meaning. I investigate declarative main clauses and subordinate clauses, looking at structural contexts where: (1) the two paradigms are in complementary syntactic distribution, e.g., where $w h$ - and focusfronting require the Focus Perfective, whereas yes/no questions and topicalization occur with the General Perfective $(\S 5)$; (2) both Perfectives are attested, e.g., historical narratives where prominent foregrounded event-clauses carrying the storyline require the Focus/Narrative Perfective, but less salient background clauses occur with the General Perfective $(\S 6)$. The correlations between form and meaning are complex, but significant generalizations are observable (see also Caron 1991, 2000).

\section{The Focus Perfective and General Perfective in Complementary Environments}

In main clauses relating to past time, the major distinction is that the default General Perfective occurs in canonical declarative constructions which are syntactically basic

\footnotetext{
${ }^{2}$ Longacre (1990:1-10) also points to a correlation between foreground information and salience and suggests that his own schema for ranking narrative clauses is in fact closely linked to the categories of transitivity set up by Hopper \& Thompson (1980).
} 
and pragmatically neutral. The Focus Perfective, on the other hand, is compatible with the derivative non-canonical counterparts which entail syntactic reordering and are pragmatically marked, i.e., focus constructions, interrogatives, and modifying (subordinate) relative clauses.

\subsection{Focus Perfective Only: Focus, wh-, and Relative Clauses}

Constituent ex situ wh-questions, declarative focus constructions and relative clauses in Hausa constitute a family of syntactically allied constructions that entail wh-movement and are marked by special inflectional morphology. Generative approaches assume that extracted $w h$-phrases carry an inherent focus feature which enables them to target the same position as focus movement, see, e.g., Schachter (1973), Hyman \& Watters (1984), Tuller (1986, and Green (1997). Example (5) illustrates a main clause ex situ wh-question (a), followed by a new information focus response (b), and entailing: (1) fronting of the discourse/addressee-new wH/focus elements to left periphery; (2) special inflectional focus marking on the preverbal Focus-Perfective TAMs; (3) an optional post-focus copula/focus marker:
(5) a. [wàa $]_{\mathrm{wH}}$ kukà (*kun) [ganii who 2 pl.foc-pfv ( ${ }^{*} 2$ pl.pfv) see at market
'who did you see at the market?'
b. [yaarònkài $]_{\mathrm{FOC}}$ nee mukà (*mun) [ganii
boy.of. $2 \mathrm{msg}$ cop 1 pl.foc-pfv $\left({ }^{*} 1 \mathrm{pl}\right.$.pfv) see
i] à kàasuwaa?
'it was your boy we saw'

Even though the obligatory choice of the Focus Perfective is syntacticallydetermined, these displacement operations have a common semantic-pragmatic property, namely the specific prominence given to the foregrounded pre-TAM element, i.e., the fronted focal wh-word 'who?' in (5a), and the fronted new information focal response 'your boy' in (5b).

The one environment where the Focus Perfective does not seem to fit semantically is in syntactically associated restrictive relative clauses, where it occurs obligatorily following movement to clause-initial position, e.g.,

(6) gàa [àbincîn $\left.{ }_{\mathrm{i}}\right]$ dà mukà (*mun) [sayoo pres food.dd subord lpl.foc-pfv (*1pl.pfv) buy

'here is the food that we bought'

Although it is not immediately obvious how the semantic-pragmatic properties "foreground/highlighting/prominence" and "new information" might be extended to 
cover such relative clause constructions-subordinate relative clauses and their antecedents can (and often do) specify addressee-old information for example - the information encoded by the headed relative clause might be regarded as "new" in terms of the association between the referent of the antecedent and the proposition concerned. Of greater relevance, however, is their specific identifying function. In (6) the postmodifying (restrictive) relative clause 'that we bought' asserts a property of the fronted NP antecedent 'the food' and so restricts/specifies/delimits etc. its denotation, and the whole clause is closely integrated into the matrix.

Important independent evidence for this form-meaning correspondence comes from the recent discovery that non-restrictive relative clauses can differ in their syntactic (TAM-selection) structure. Some speakers, for example, will allow a General Perfective (or Imperfective), as an alternative to the (more common) Focus Perfective in the non-restrictive version (Jaggar 1998), e.g.,

(7) đàalìbân, wàdàndà sun (sukà) gamà aikìnsù, duk sun tàfi students.dd relpro 3pl.pfv (3pl.foc-pfv) finish work.of.3pl all 3pl.pfv leave 'the students, who have finished their work, have all left'

Compare the corresponding restrictive relative where only the Focus Perfective is licensed:

(8) dàalìbân dà sukà (*sun) gamà aikìnsù duk sun tàfi students.dd subord 3pl.foc-pfv (*3pl.pfv) finish work.of.3pl all 3pl.pfv leave 'the students who have finished their work have all left'

This variation is of real interest and is explicable in semantic-pragmatic terms. Nonrestrictives such as (7) are only loosely connected to surrounding materials and so, like topicalization $(\$ 5.2 .3)$, do not restrict/affect the designational properties of the head. The additional information they convey is supplementary and backgrounded ("de-emphasized"), and plays no role in identifying the referent.

\subsection{General Perfective Only}

5.2.1. Declarative statements in main clauses. In simple affirmative declarative clauses which denote past-time propositions, only the General Perfective occurs, and it overlaps in meaning with both the English Simple Past (Preterite) and Perfect, e.g.,

(9) taa yar̃ dà makullintà 3fsg.pfv lose key.of.3fsg 'she lost her key' 
Sentence (9) is equivalent to either a context-dependent 'she lost her key' (Simple Past), or 'she has lost her key' (Perfect) where the action has just been completed in the recent past and is relevant to the time of speaking. The General Perfective can therefore be used to describe the occurrence of events and situations within a timeframe up to 'here-and-now', i.e., situations viewed as the consequence of some (recent) past event. The TAM remains the same even if it occurs in a subordinate clause which is embedded within a matrix clause containing a Focus Perfective, e.g.,

(10) Bàlaa nèe ya gayàa minì taa yar̃ dà makullintà

Bala cop 3msg.foc-pfv tell lsg.i.o. 3fsg.pfv lose key.of.3fsg

'it was Bala (who) told me she (had) lost her key'

The General Perfective is also used with future time-reference (= English Future Perfect), e.g., (anterior to future),

(11) raanaa yì ta gòobe naa kammàlà aikìn day like tomorrow 1 sg.pfv finish work.dd 'a week tomorrow I will have finished the work'

The pragmatically neutral General Perfective is used in a number of related "timeless" contexts where no specific time is entailed, and where English would use a simple present tense, for example, with most semantically stative verbs such as perceptual, cognitive and entry-into-state verbs:
(12) naa yàr̃a
'I agree'
1 sg.pfv agree
(13) mun gaanèe
'we understand'
1 pl.pfv understand
(14) naa kòoshi
'I'm full (sated)'
1 sg.pfv be full

In (12-14) the atelic states are construed as still existing completed wholes, but persisting over an unlimited time (Comrie 1976:48). The same grammatical TAM construction is used with (dynamic) performative verbs, where the action is seen as completed by being stated, and with communicative verbs, e.g.,

(15) naa yi àlkawãñi zân kaawoo makà

1 sg.pfv do promise fut. 1 sg bring $2 \mathrm{msg}$.io

'I promise I'll bring (it) to you' 
(16) maalàminkà yaa gayàa minì kaa ci jarr̃àbâawâr teacher.of.2msg 3msg.pfv tell 1sg.io $2 \mathrm{msg}$.pfv pass exam.dd 'your teacher tells me you passed the exam'

Linked to its stative usage, the General Completive is also used to express generic events which hold for all time, including proverbs, e.g., ${ }^{3}$

(17) shiddà taa fi biyu six 3fsg.pfv exceed two

(18) ganii yaa kòori jîi seeing 3msg.pfv drive away believing 'six is greater than two'

'seeing is [has driven away] believing'

The General Perfective can also occur in past-time sequences of multiple (two or more) coordinate clauses., e.g.,

(19) yâaraa sun yi aikìi sun gàji

children 3pl.pfv do work 3pl.pfv be tired

'the children (have) worked and (have) got tired'

A timeless General Perfective is used in coordinate stage directions, e.g.,

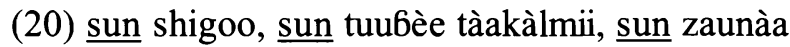

3pl.pfv come in 3pl.pfv take off shoes 3pl.pfv sit down

'they come in, take off their shoes, and sit down'

One of the defining properties of historical narrative event-clauses is that they are linked in sequence. In (19) and (20), the events are sequential but do not relate to a real narrative discourse with discrete time-points viewed in their totality. Such a narrative sequence would require the Narrative/Focus Perfective, and would also typically include a connective adjunct such as sai 'then', e.g.,

(21) sukà shigoo, sukà tuu6èe tàakàlmii, sai sukà zaunàa

3pl.narr-pfv come in 3pl.narr-pfv take off shoes then 3pl. narr-pfv sit down

'they came in, (they) took off their shoes, then (they) sat down'

${ }^{3}$ Hausa also has a set of forms, equivalent to English wh-ever compounds, composed of koo 'whether, if' plus a wh-word, e.g., koowàa = koowaa 'whoever'. The koo-word is in pre-TAM position and functions as the head NP of a modifying relative clause (§5.1), e.g., zân bâa koowàa ya zoo 'I'll give (it) to whoever comes' (fut.1sg give whoever $3 \mathrm{msg}$.foc-pfv come). Although the $k o o$-word is semantically non-referential, the Focus Perfective is forced here by the syntax. 
The General Perfective is also used in headlines, story titles, and captions, e.g.,

(22) An Haràmtà Auren Yâaraa 'Marrying Children is/has been Outlawed' 4pl.pfv outlaw marrying.of children

The General Perfective is also common in past-time reportative news contexts, and a string of recent-past situations can all use the TAM in multiple coordinate main clauses, e.g., (Jaggar 2001:157):

(23) wani đan-jãriiidàa yaa fadàa wà gidan r̃eediyòn $\mathrm{BBC}$ cêewaa har̃kookin cìnikii sun tsayàa cik à yawancin kasâr. An tsai dà yawancin har̃kookin cìnikii an kuma rufêe shaagunàa.

'A reporter (has) told the BBC that trading activities (have) ground to a halt in most of the country. Most trading activities have been stopped and shops have been closed.'

The Perfective TAM in (23) assumes the General form because the past situation is viewed as having "current relevance"-hence the Past Perfect English equivalentsand so could comfortably take a present-time adverb such as yànzun-nàn 'just now'. Again, however, if the reported events in (23) were being related as a historical narrative sequence, then only the Narrative Perfective would be admissible, i.e., ... har̃kookin cìnikii sukà tsayàa cik à yawancin kasâr, akà tsai dà yawancin har̂kookin cìnikii akà kuma rufêe shaagunàa '...trading activities ground to a halt in most of the country, most trading activities were stopped and shops were closed'. Here the focus is on the realization of the temporally-ordered mainline events in the past, not their "current relevance", since the Focus Perfective is indifferent to the temporal distance between the reference time and utterance time. Notice, however, that if a focus $/ w h$ - or relative construction intervened within a reportative General Perfective fragment, this would force a Focus Perfective TAM, e.g. (in the middle of a news report), ... dàa jirgin samà nee ya yi hatsàrîn... '... if a plane had had the accident...' (if plane cop(msg) 3msg.foc-pfv do accident.dd), with a focussed constituent 'plane'.

5.2.2. Yes/no questions. Unlike $w h$-questions which require the Focus Perfective following movement of the inherently focal wh-element, yes/no questions preserve the declarative structure and only allow a default General Perfective, e.g.,

(24) kin kaawoo ruwaa koo?

'did you bring the water or not?'

2 fsg.pfv bring water or 
(25) Audù yaa sàyi mootàa? 'did Audu buy a car?'
Audu 3msg.pfv buy car

5.2.3. Topicalization. When a constituent is topicalized in front position with a relevant discourse-old link to other items in the preceding discourse (a rule also known as "non-focus preposing"), only the General Perfective is admissible, e.g.,

(26) a. Àkwai màalàmai dà yawàa à makar̃antar̃mù. exist teachers many at school.of. $1 \mathrm{pl}$

b. [Wasu naa $\left({ }^{*}\right.$ na) sanìi], [wasu bàn sanìi ba] sid 1sg.pfv (*1sg.foc-pfv) know sid neg.pfv.1sg know neg 'There are many teachers at our school. [Some I know], [some I don't know]'

Although left-dislocated topics and focus-fronted constituents occur sentence-initial, a major syntactic difference is the absence of special inflection on the TAM which indicates that topics are base-generated, i.e., not displaced like focus constituents (see Green \& Reintges 2005:38ff. for a detailed account of the formal properties). There are also key semantic-pragmatic differences. In topicalized constructions, the topic expression often represents addressee/discourse-old information and so is independently specified/ identified. This is in contrast to focus constructions, both new information or exhaustive/exclusive, where the focus expression typically represents the salient addressee/discourse-new information.

5.2.4. Subordinate adverbial clauses. Although the form-function correlations of the two Perfectives are typically complex rather than one-to-one, the distribution of the two sets in subordinate environments is basically consistent with the pervasive structural-semantic correlation that the primary (deictic) use of the Focus Perfective is to signal realis, single-occurrence events which are anterior to the utterance time, and so is much closer to being a tense. When these conditions do not apply, the default General Perfective occurs. (For more supportive data see Wolff (1993: chap. 7), Newman (2000: chap. 70), Jaggar (2001: chap. 6), and especially Bagari (1987) and Schuh (n.d.a, n.d.b).)

One set of constructions that is especially instructive is the conditional. Because conditional clauses entail non-factuality, and are not used to make a positive assertion of any kind, with the partial exception of open conditionals (29), there is a systematic association with the General Perfective. In remote and concessive conditional clauses, the Focus Perfective would be semantically incompatible, and only the unmarked default General Perfective occurs, e.g., 
(27) dàa kin (*kikà) gayàa manà dàa mun (*mukà) shiryàa mikì àbinci if 2 fsg.pfv (*2fsg.foc-pfv) tell 1pl.i.o. then 1pl.pfv (*1pl.foc-pfv) prepare 2 fsg.i.o. food 'if you had told us then we would have prepared some food for you'

In (27) the past-time remote (counterfactual) conditional describes an imaginary situation which is different from the real world-we understand that you did not tell us - so only the General Perfective is licensed in both the protasis and apodosis to express this modal remoteness (notice that English would use a modal auxiliary in the matrix apodosis).

(28) kanàa iyà gaanèe shi koo yaa canzà muryàr̃à

$2 \mathrm{msg}$.impfv can recognize $3 \mathrm{msg}$ even if $3 \mathrm{msg}$.pfv change voice.of. $3 \mathrm{msg}$

'you can recognize him even if he changes (has changed) his voice'

In (28) the truth of the initial main clause might be considered false in the light of the information in the subordinate concessive clause. The form-meaning correlation is strong but not exceptionless, however. In open if-conditional clauses the two Perfectives actually compete and can both be used in contexts without specific reference to present time, e.g.,

(29) ìdan kin/kikà kaawoo aikìn gòobe, zân duubàa shi [future time]

if 2 fsg.pfv/2fsg.foc-pfv bring work.dd tomorrow fut. 1 sg look at $3 \mathrm{msg}$

'if you bring (have brought) the work tomorrow, I'll look at it'

In (29) the time of [you bringing the work] is understood as a future time later (posterior to) than now, but still anterior to [me looking at it]. Speakers seem to have a free choice in open conditionals, i.e., the two sets unusually share syntactic distribution here, and the semantic distinction between the Focus Perfective and General Perfective is breaking (or has broken) down. (Cf. English, where the basically deictic Past/Preterite tense can depart from its past-time primary meaning and be used in a subordinate clause to express a modal remote conditional in the future, e.g., 'if you came tomorrow, that would be better'.)

In subordinate temporal 'when' clauses, the conjunction dà 'when' is used with the Focus Perfective to recapitulate a past-time event-clause in foreground narrative (§6.2), e.g.,

(30) sai ya dâukee kwàndôn ... dà ya đâukee kwàndoo đaya ... then 3msg.narr-pfv take basket.dd when 3msg.foc-pfv take basket one 'then he took the basket ... when he had taken the one basket ...' 
In (30) the background clause 'when he had taken the one basket' repeats the eventclause just mentioned and is introduced by dà 'when' + Focus Perfective (this subordinate clause is not part of the narrative sequence and the Focus Perfective is syntactically required here after the (relative) dà conjunction, see §6.2). If the same conjunction is used to introduce a subordinate 'when (as soon as)' clause in the future, however, then it takes the General Perfective, e.g.,

(31) dà kaayân sun isoo, zân gayàa makà when goods.dd 3pl.pfv arrive fut. 1 sg tell $2 \mathrm{msg}$.i.o.

'when/as soon as the goods arrive (have arrived), I'll tell you'

There are also some paired subordinators with equivalent past-time meaning such as baayân dà and baayan 'after' where the relative form baayân dà (back.the which) takes a syntactically required Focus Perfective and the non-relative counterpart baayan (back.of) takes a General Perfective, e.g. (from Bagari 1987:87),

(32) a. sun yi barcii baayân dà sukà ci àbinci

3pl.pfv do sleep after 3pl.foc-pfv eat food

$=\mathrm{b}$. sun yi barcii baayan sun ci àbinci

3 pl.pfv do sleep after 3pl.pfv eat food

'they slept after they had eaten'

With future time reference, however, only baayan 'after' + General Perfective is licensed in the subordinate clause (the essentially "past time in relation to the hereand-now" Focus Perfective would again be semantically inadmissible), e.g.,

(33) baayan kun gamàa, sai mù tàfi after 2pl.pfv finish then 1pl.sjnctv go 'after you have finished, then we can go'

As regularly exemplifed throughout, the connective adjunct sai 'then' frequently occurs in foreground narrative event-clauses with a following Narrative Perfective, e.g. (non-subordinate clauses, see Appendix B),

(34) sai ya yi karòo dà duutsèe, sai ya faadî dà kèekên, then 3msg.narr-pfv do collision with rock then 3msg.narr-pfv fall with bike.dd duk sai mangwàròn ya zubèe all then mango.dd 3msg.narr-pfv spill 'then he bumped into a rock, then he fell with the bike, then the mangoes all spilled' 
Sai can also function as a negative-oriented subordinator '(not) until', indicating a future-time endpoint. In such contexts, however, it takes the neutral General Perfective in the subordinate clause, e.g.,

(35) bàa zân biyaa kà ba sai kaa gamà aikìn neg fut. 1 sg pay $2 \mathrm{msg}$ neg until $2 \mathrm{msg}$.pfv finish work.dd

'I won't pay you until you have finished the work'

\section{The Narrative (Focus) Perfective and General Perfective: Contrastive Functions in Narrative}

Past-time narrative is a key domain where both Perfective paradigms are attested but where the on-line selection is based on intrinsic meaning and pragmatics. As already noted, the core function of both the General Perfective and Focus Perfective is to express the temporal notion of anteriority, i.e., a time preceding the time-orientation expressed by other elements in the sentence (or the speech context), typically the moment of speaking. Examples (36) and (37) are declarative statements containing General and Narrative Perfective forms respectively, and both locate the time referred to (TR) as anterior to (<) the time of speaking (or writing), i.e., the time of orientation (TO), and TR also coincides with the time of situation (TS):

$\begin{array}{ll}\mathrm{TR} / \mathrm{TS}<\mathrm{TO} & \begin{array}{l}\text { yaa mutù } \\ \text { 3msg.pfv die } \\ \text { 'he (has) died' }\end{array} \\ & \begin{array}{l}\text { a. } \quad \ldots \text { dà ya daawoo, } \\ \text { when 3msg.foc-pfv return }\end{array} \\ \mathrm{TR} / \mathrm{TS}<\mathrm{TO} & \text { b. } \quad \begin{array}{l}\text { sai ya mutù } \\ \text { then 3msg.narr-pfv die } \\ \text { [... when he had returned, then he died' }\end{array}\end{array}$

In both (36) and (37) the time of dying (TR) is coextensive with the time of situation (TS) and is construed as a time-point earlier than the here-and-now time of orientation (TO). Despite this unified semantic property of anteriority, however, there is an important functional difference-whereas use of the General Perfective yaa mutù in (36) simply denotes a state (and is translatable with a context-dependent English Past/Preterite 'he died' or Present Perfect 'he has died'), the Focus Perfective ya mutù in $(37 \mathrm{~b})$ is performing its canonical discourse function of tracking a specific occurrence on the past time-axis. This is a prototypical narrative sequence: the initial background subordinate clause (37a) 'when he had returned' 
interrupts the narrative flow by repeating the foreground event-clause just mentioned, and is introduced by the subordinator dà 'when' and a Focus Perfective (this is syntactically required because dà is in fact an ellipted variant of the complex relative NP subordinator lookàcîn dà 'the time that'). The narrative is then resumed in (37b) with an event-clause sai ya mutù 'then he died' introduced with the connective adjunct sai 'then' and a Narrative Perfective. In such contexts the two paradigms are in complementary syntactic distribution-substituting the narrative form ya in (36), or the neutral form yaa in (37b) would result in ungrammaticality.

Note that because there is no single overt tense-aspect marker of narrative foregrounding in English, an out-of-context sentence like 'she went to university' (simple Past Tense) could occur simply as: (a) a background, marginal event or statement/response in conversation, e.g., 'she went to university and got a degree', or (b) as one in a series of foregrounded events in a narrative sequence, e.g., '...then she went to university and got a degree and became a teacher'. In Hausa, however, the two clauses would be unambiguously distinguished in the syntax because narrative foregrounding is grammaticalized, cf. (38) and (39).

(38) taa jee jaami'àa taa sàami dìgîrîi

3 fsg.pfv go university $3 \mathrm{fsg}$.pfv get degree

'she went to university and (she) got a degree'

(39) sai ta jee jaami'àa ta sàami dìgîrîi ta zama maalàmaa

then 3 fsg.narr-pfv go university 3 fsg.narr-pfv get degree $3 \mathrm{fsg}$.narr-pfv become teacher

'...then she went to university and (she) got a degree and (she) became a teacher'

We now turn to consider the use of the Focus Perfective to guide the addressee through the fabric of the story by highlighting new, foreground events as expressed in the verbal predicates of past-time narratives. As we have seen $(\S 5.1)$, these criterial semantic/pragmatic features-foregrounding and addressee-new information status - also characterize fronted focus and wh-constructions, and it is this key observation which explains why these intersentential and sentence-internal constructions form a natural class and so are marked by the same tense-aspect morphology.

\subsection{The Focus Perfective in Foreground Historical Narrative Sequences}

A historical narrative discourse, as defined by Longacre (1990:1-2), is a storyline developed by clauses in which the verbs encode a series of often punctual and 
volitional/agential actions in chronological sequence, each of which initiates a new situation, and directed to a climax. A canonical past-time narrative also differs from other discourse types by including what Longacre terms "cohesive" clauses which contribute to the textual cohesion and narrative progression. In Hausa these clauses are usually initiated by connective adjuncts such as (sequential and anaphoric) sai 'then (after that)', sànnan = sânnan 'then' (that time), or (recapitulatory) dà 'when' (see exx. above). There are several related semantic/pragmatic properties which together characterize and motivate the Hausa Narrative Perfective in foregrounded narrative main clauses, features which are generally accepted as the important defining characteristics across languages. Thus, the backbone chain events encoded by the Narrative Perfective have the following criterial design features. They must be: (1) anterior to the utterance-time (as specified above); (2) single-occurrence, telic, complete units; (3) linked in sequence by the speaker to specific time-points. (This definition is in fact close to Quirk et al's (1985:183) characterization of the English "Definite Past" tense, minus the sequentiality condition (3).) The verbs in the Narrative Perfective predicates also usually express punctual and conceptually bounded actions (though the link between perfective marking and situations involving telic punctual accomplishments requires another paper).

Cross-linguistic studies also indicate that the distinction between background and foreground clauses is a universal attribute of narrative discourse (see Hopper 1979, 1982 on aspectual markers in narrative). Speakers need to distinguish reference to the main (foreground) actions from supporting (background) information and so exploit tense-aspect to navigate their way through the storyline, often using a specific verbal paradigm for foregrounding. Foregrounded clauses are the backbone of the narrative and assert realis events and results, functioning to move the sequential narrative forward; settings and causes, on the other hand, are interpreted as background, with states usually serving supporting roles. In the prototypical case, and except when a new (agential) subject is introduced, foregrounded pivotal clauses in narrative also contain in their predicates the communicatively prominent addressee/discourse new information, i.e., each event leads to a new situation. In Hausa this is a key compositional property shared with new information focus (and wh-) constructions, and so they attract the same Focus/Narrative Perfective marking. ${ }^{4}$ (For various treatments of the universal foreground vs. background

\footnotetext{
${ }^{4}$ Biber (1984) documents an analogous situation in Central Somali, where clause-level constituent focus and foregrounded narrative clauses use the same focus particle yaa. See also Anderson (1979:86ff.) and Hyman \& Watters (1984:258) on Aghem, a Cameroonian Grassfields Bantoid
} 
distinction, see Labov (1972), Grimes (1975), Reinhart (1984), Matthiessen \& Thompson (1988), Longacre (1990), and especially Hopper (1979, 1982) and Hopper \& Thompson (1980).) Fragment (40), taken from the narrative in Appendix $B$, illustrates a prototypical sequence of foreground, same-subject clauses:

(40) a. Shiikèenan, sai ya [hau kân]...

that was that then 3msg.narr-pfv climb on

b. ya [faarà tuurà kèekènshì], 3msg.narr-pfv begin push bike.of.3msg

c. ya [yi tàfiyàrĩshì].

3msg.narr-pfv do go.vn.of.3msg

'That was that, then he got on ... he started to push his bike, and he went on his way.'

In (40) the verb, as the syntactic predicator and head of the VP, is the principle mechanism for advancing the flow of new information in the narrative. The new events are introduced in the three predicates (a) [got on], (b) [started to push his bike], and (c) [went on his way], and the presupposed subject referent is identical throughout. The discourse status of this new focal information is marked by the recurring affirmative Narrative Perfective subject element $y a$.

Although foregrounded clauses typically refer to the same subject participant performing the sequential narrative actions, i.e., there is continuity of referent, action, time, and place, it is of course possible to get a change of subject, e.g.,

(41) a. Ya yi tàfiyàrshì 3msg.narr-pfv do go.vn.of.3msg

b. Tôo, àshee yaa bar̃ hùular̃sà à wurîn dà akà yi karòn, well but $3 \mathrm{msg}$.pfv leave hat.of.3msg in place.dd subord 4pl.foc-pfv do collision.dd

c. sai wani yaaròo sai ya ga hùulẫ.

then sid boy then 3 msg.narr-pfv see hat.dd

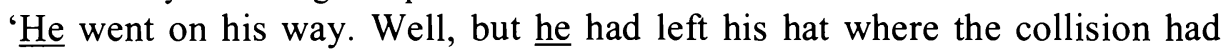
taken place, then a boy saw the hat.'

In (41c) it is in fact the whole proposition expressed in the event-clause 'then a boy saw the hat' which represents the new foregrounded information (or alternatively the subject + (predicator) verb without the old information complement 'the hat'). Example (42) illustrates another typical narrative device entailing repetitious co-

language, where the same tense-aspect form expresses both the (narrative) "Consecutive Tense" and (predicate) "Completive Focus". 
ordination of a string of event-line clauses each initiated by connective-anaphoric $s a i$ 'then (after that)'. Temporal sai refers to a time closely following the antecedent event in the preceding clause and signals entry into the next new foreground event, each with a Narrative Perfective, i.e., sai [event 1] ..., sai [event 2] ..., sai [event 3] ... etc., with sai identifying each subsequent point in the narrative, e.g.,
a. ... sai Karfèn tayàa ya kar̃cèe tiitìi, then metal.of tyre 3msg.narr-pfv scrape road

b. sai wutaa ta yi tàrrtsatsii hakà. then fire 3 fsg.narr-pfv do sparks thus

c. Shiikèenan sai ya tàfi can. that was that then $3 \mathrm{msg}$.narr-pfv go there

'... then the metal rim scraped on the road, then the fire produced sparks like that. That was that then he (the driver) went off.'

The clause-initial shiikèenan 'that was that' in (42c) is another common anaphoric connective in discourse - its antecedent event is signaled by the Narrative Perfective tense-aspect in the preceding clause (b) - and it can in fact combine with sai 'then' as here. Shiikèenan tends to be more "disruptive" than sai, however, and can signal a juncture in the narrative flow, e.g., a theme-switch or transition to a new episode, action sequence, or "idea unit" (Chafe 1980):

(43) a. Mukà jee bìkin wani àbookinmù.

1pl.narr-pfv go party.of sid friend.of. $1 \mathrm{pl}$

b. Shiikèenan mun jee can gàban Bàgàuda nèe, à Kanòo.

$\mathrm{OK} /$ that was that $1 \mathrm{pl}$.pfv go there beyond Bagauda cop in Kano

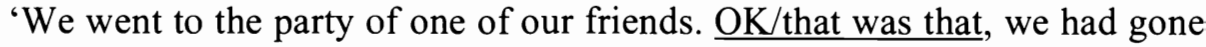
way beyond Bagauda, in Kano.'

\subsection{TAMs and other Strategies in Background Narrative Clauses}

Although it is impossible to do justice to all aspects of the phenomenon of grounding in Hausa narrative discourse, we now turn briefly to consideration of the various non-Narrative Perfective TAMs and other strategies which are commonplace in the background portions of narratives. In historical narratives, as we have seen, speakers distinguish the foreground from the background largely by the use of tense-aspect morphology. The background functions to provide supportive material that elaborates or evaluates the focal events in the foreground, and like subordinate clauses, it often signals causes, reasons, conditions, means, etc. Background may also provide orientation, or explanation and identification, and I 
will draw on some of Longacre's (1990:4) terminology to describe the various departures from the linear sequence of event-clauses, e.g., scene-setting, evaluations (author intrusions), etc. The TAMs frequently encountered in background contexts are the General Perfective, the quasi-modal Subjunctive and Future, and the Imperfective (see also Burquest 1991, 1992).

As already noted, the General Perfective encodes a non-deictic past event in background narrative sequences, locating a situation as anterior to an intermediate time referred to which is itself anterior to the time of the utterance, and so is equivalent to a 'had' Past Perfect in English, e.g., (see text Appendix A),

(44) a. na buuđèe, tôo daree yaa faarà yîi

1 sg.narr-pfv open well night 3msg.pfv start do.vn

b. sai Karfèn tayàa ya kar̃cèe tiitìi.

then metal.of tyre $3 \mathrm{msg}$.narr-pfv scrape road

'I opened (the door), well night-time had arrived, then the metal rim scraped on the road.'

In terms of information processing the General Perfective form in clause (44a) maps supportive background information, and contributes to the interpretation of the key foreground events by signalling prior events outside the main sequential time-line. The same TAMs in (45) are evaluative and external to the narrative itself:

(45) a. Na kaasà maa buudèe Koofàa

1 sg.narr-pfv be unable even open door

b. sabòodà naa giggìcee,

because 1sg.pfv panic

c. duk naa zàtaa duk sun rìgaa sun mutù.

all 1sg.pfv think all 3pl.pfv do already 3 pl.pfv die

d. Na buudèe ....

1sg.narr-pfv open

'I couldn't even open the door because I'd panicked, I thought that they had all died already. I opened...'

In (45) the narrative temporal sequence (45a) is interrupted by a string of General Perfective verbs which provide causal evaluation on the part of the speaker. The subordinate clause (45b) sabòodà naa giggìcee 'because I'd panicked' contains a stative (emotion) verb giggicee, followed by evaluative (c) duk naa zàtaa duk sun rìgaa sun mutù 'I thought that they had all died already'. Together, they provide an assessment of the speaker's state of mind and motivation at the time, before he then re-enters the narrative flow in $(45 \mathrm{~d})$. 
Future and subjunctive TAMs in background clauses are used to make a prediction about the outcome of an irrealis event (located after the event on the main time-line), e.g. (from Appendix B),

(46) a. Shiikèenan, yaa cikà kwàndoo gùdaa biyu,

OK 3msg.pfv fill basket unit two

b. yaa hau kân mangwàròn,

3msg.pfv climb top.of mango tree.dd

c. zâi jee,

fut.3msg go

d. don yà tsinkoo mangwàròòn

so as to $3 \mathrm{msg}$.sjnctv pick mango.dd

e. dà zâi cikà kwàndonshì na kàrshee, subord fut.3msg fill basket.of.3msg of last

f. shii kwàndoo na ukù.

$3 \mathrm{msg}$ basket of three

'(a) OK, he had filled two baskets, (b) he had climbed the mango tree, (c) and he was about to go, (d) so he could pick the mangoes (e) that he would fill his last basket with, (f) the third basket.'

In (46) the narrative is suspended by two flashback General Perfective clauses (a, b), followed by a projective Future TAM (c) and a Subjunctive clause (d) with another Future embedded in the relative clause (e). These elaborative background clauses serve to explain and justify the subsequent narrative action.

The temporal adjunct dà 'when', as noted above, is regularly used as a narrative device to initiate a cohesive background clause which anaphorically recapitulates the event in a previous clause, e.g.,

(47) a. ya baa shì, ya cèe gàa hùular̃shì.

$3 \mathrm{msg}$.narr-pfv give $3 \mathrm{msg} 3 \mathrm{msg}$.narr-pfv say present hat.of. $3 \mathrm{msg}$

b. Shiikèenan, dà ya baa shì hùulâr̃ ...

OK when 3 msg.foc-pfv give $3 \mathrm{msg}$ hat.dd

'he gave him (the hat), he said here was his hat. OK, when he had given him the hat...'

In $(47 b)$ the orientation subordinate clause 'when he had given him the hat' is interpolated to repeat the event in the preceding clause (47a). Notice that because dà 'when' requires the Focus Perfective-it is a reduced form of the complex relative NP subordinator lookàcîn dà 'the time that', cf. 48c - the formal contrast between 
the foreground Narrative Perfective and background (past-in-the-past) General Perfective is neutralized. An identical neutralization is exemplified in (48b):

(48) a. ... mù duubà

1 pl.sjnctv see b. mèe ya fàaru.

what 3msg.foc-pfv happen

c. Àshee lookàcîn dà sukà faadàa raamìn, well when 3pl.foc-pfv fall into hole.dd

d. sai sukà faadàa cikin tàboo ... then 3pl.narr-pfv fall into mud '... to see what had happened. Well, when they had fallen into the ditch, then they fell into some mud...'

Although (48b) mèe ya fâaru 'what had happened' is a flashback clause, the presence of the wh-word triggers an obligatory Focus Perfective, together with the grammatically required form in (48c) lookàcîn dà sukà faadàa raamìn 'when they had fallen into the ditch'. Notice how the speaker then initiates another narrative sequence with sai 'then' in (48d).

The Imperfective expresses incomplete durative-progressive action, and often occurs in narrative background to express an event simultaneous with the narrative progression. Such orientation clauses provide background information, e.g.,

(49) a. Munàa daawôowaa dàgà lìyaafâa.

1 pl.impfv return.vn from entertainment

b. Tôo, àkwai mootoocii wajen goomà dà mukà tàfi dà suu.

OK exist cars about ten subord 1pl.foc-pfv go with 3pl

c. Muu munàa cikin kàramar̃ mootàa nee, Daihatsu.

1 pl 1pl.impfv in small.of car cop Daihatsu

'We were returning from the entertainment. $\mathrm{OK}$, there were about ten cars that we'd taken. We were in a small car, a Daihatsu.'

In $(49 \mathrm{a}, \mathrm{c})$ the Imperfective is used to signal the background circumstantial clauses 'we were returning from the entertainment' and 'we were in a small car, a Daihatsu'. These orientational TAMs express ongoing actions which overlap with the mainline narrative events.

Finally, new participants (or props) are typically introduced by deictic function words such as existential àkwai 'there is/are' $(49 \mathrm{~b}, 50 \mathrm{~d})$, presentative gàa 'here/there is/are' (47a, 51a), and the copula nee $(\mathrm{msg} / \mathrm{pl})$, cee (fsg) (52a), and all such non-verbal clauses provide descriptive orientation for the ensuing material. The following clause often contains a motion verb, with a Narrative Perfective TAM 
if the speaker views it as part of the foreground narrative (52b), or a default General Perfective if the event is perceived as part of the background (50e, 51b). Examples:

(50) a. Shiikèenan sai ya tàfi can. that was that then $3 \mathrm{msg}$.narr-pfv go there
b. Mun dâukee kân mootàa
c. don kâr̃ mù bugèe shi, 1pl.pfv take head.of car in order neg 1 pl.sjnctv hit $3 \mathrm{msg}$
d. can kuma àkwai bàbbar̃ mootàa, there and exist big.of car
e. taa tahoo. 3 fsg.pfv appear

'(a) That was that then he went off. (b) We had changed direction (c) so as not to hit him, (d) and in the distance there was a lorry, (e) it had appeared.'

(51) a. Can à kân hanyàa sai kuma gàa wata yaarinyàa, there on road then also present sid girl

b. taa tahoo dàgà wani gurii. 3 fsg.pfv appear from sid place

'Later on there was a girl, she had appeared from somewhere'

(52) a. Dà farkoo dai wani mùtûm nee, at first actually sid man cop b. ya jee... 'First of all actually there's (it's) a man, he went....'

Following the single Narrative Perfective clause in $(52 \mathrm{~b})$, the speaker then moves off the event-line and sets the scene with a string of ten background clauses before re-entering the narrative (see Appendix B).

\section{Summary and Conclusions}

The key claim advanced and supported here is that the obligatory occurrence of the Focus/Narrative Perfective TAM in both focus/wh-constructions and main clause historical narrative is not accidental, despite the apparent diversity of these phenomena. Various structural, semantic and pragmatic constraints either restrict or favour the variation in the use of the two Perfective paradigms. Thus, in contrast to the unmarked default General Perfective, the Focus Perfective is a specialized inflectional set whose primary use is to encode bounded single-occurrence events and situations which are anterior to the utterance-time. Focus/wh-and foreground narratives all involve elements that are highly salient/prominent in the discourse context. Focus/wh- expressions entail syntactic fronting/preposing of constituents, 
and pragmatically foregrounded event-clauses in narrative sequences are formally marked with the same special tense-aspect morphology. All these related constructions - sentence-level focus/wh- and intersentential event-line predicate focus - involve foregrounding or highlighting of an addressee-new element as the most informative element in the clause and so constitute a natural class. Finally, this unified account owes its stimulus to some of Russell Schuh's earlier insights into the Hausa TAM system, where he investigated the distinctive syntactic and semantic features of the various inflectional categories in order to explain their functional distribution in naturally-occurring discourse.

ApPEndix A: Rân Dà Na Yi Kusan Mutuwàa "The Day I Nearly Died" (Note: Single underlining, e.g., ya, indicates (affirmative) Narrative/Focus Perfective; broken underlining, e.g., yạa, indicates General Perfective.)

\begin{tabular}{|c|c|}
\hline (1) Wata raanaa nèe dai, & (1) It was one day actually, \\
\hline (2) mukà jee bìkin wani àbookinmù. & $\begin{array}{l}\text { (2) we went to the party of one of our } \\
\text { friends. }\end{array}$ \\
\hline $\begin{array}{l}\text { (3) Shiikèenan mùn jee can gàban } \\
\text { Bàgàuda nèe, à Kanòo. }\end{array}$ & $\begin{array}{l}\text { (3) OK we had gone way beyond Bagauda, } \\
\text { in Kano. }\end{array}$ \\
\hline (4) Munàa daawôowaa dàgà lìyaafâa. & $\begin{array}{l}\text { (4) We were returning home from the } \\
\text { entertainment. }\end{array}$ \\
\hline $\begin{array}{l}\text { (5) Tôo, àkwai mootoocii wajen goomà dà } \\
\text { mukà tàfi dà suu. }\end{array}$ & $\begin{array}{l}\text { (5) OK, there were about ten cars which } \\
\text { we had taken. }\end{array}$ \\
\hline $\begin{array}{l}\text { (6) Muu munàa cikin kàramar̃ mootàa nee, } \\
\text { Daihatsu. }\end{array}$ & (6) We, we were in a small car, a Daihatsu. \\
\hline (7) Shiikèenan àkwai mootàr àbookinmù, & (7) OK, there was our friend's car, \\
\hline (8) tanàa baaya. & (8) it was behind. \\
\hline (9) Sai ya zoo & (9) Then he came up \\
\hline (10) ya ficèe mu. & (10) and passed us. \\
\hline (11) Yaa ficèe mu kèenan, & (11) Just as he had passed us, \\
\hline (12) sai tayàr̃sà ta baaya ta yi bindigàa. & (12) then his back tyre blew out \\
\hline $\begin{array}{l}\text { (13) Shiikèenan, sai ya yi ‘jaaaaa’ à } \\
\text { gàbanmù, }\end{array}$ & $\begin{array}{l}\text { (13) That was that, then he went 'rrrr' in } \\
\text { front of us, }\end{array}$ \\
\hline (14) mootàa ta yi juuyàa & (14) the car turned over \\
\hline (15) ta kađàa à gàbanmù. & (15) and swerved in front of us. \\
\hline (16) Yanàa kadàawaa, & (16) He was swerving, \\
\hline (17) tôo daree yaa faarà yîi, & (17) well night-time had come, \\
\hline
\end{tabular}




\begin{tabular}{|c|c|}
\hline (18) sai karfèn tayàa ya kar̃cèe tiitìi, & $\begin{array}{l}\text { (18) then the metal rim of the tyre scraped } \\
\text { on the road }\end{array}$ \\
\hline (19) sai wutaa ta yi tàr̃tsatsii hakà. & (19) then the fire made sparks like that. \\
\hline (20) Shiikèenan sai ya tàfi can. & (20) That was that then he went off. \\
\hline (21) Mun dâukee kân mootàa & (21) We had changed direction \\
\hline (22) don kâr̃ mù bugèe shi, & (22) so as not to hit him, \\
\hline (23) can kuma àkwai bàbbar̃ mootàa, & (23) and in the distance there was a lorry, \\
\hline (24) taa tahoo. & (24) it had appeared. \\
\hline (25) Mun zàci maa & (25) We even thought \\
\hline (26) mootàa ta baayanmù zaa tà zoo & (26) the car behind us would come \\
\hline (27) tà hadàa dà ta gàbanmù, & (27) and collide with the one in front of us, \\
\hline (28) tà naanèe gàbaa daya, & (28) and crush (it) in one go, \\
\hline (29) duk mù tàfi. & (29) and we would all die. \\
\hline (30) Àmmaa Allàh ya kiyàayee, & (30) But God protected us, \\
\hline (31) sai ita mootàr ta yi can & (31) then that car went off \\
\hline (32) ta faadàa cikin wani raamìi. & (32) and plunged into a ditch. \\
\hline (33) Tôo, kàafin mù jee & (33) OK, before we could go \\
\hline (34) mù tsayàa à bàakin tiitìi, & (34) and stand by the side of the road, \\
\hline (35) duk gàbanmù yanàa ta faadùwaa, & (35) we were in a state of shock, \\
\hline (36) don mun daukàa & (36) because we assumed \\
\hline (37) wadàncân sun faadàa raamìi & (37) those people had fallen into the ditch \\
\hline (38) duk gàbaa daya sun mutù. & (38) and had all instantly died. \\
\hline (39) Akà cêe & (39) I was told \\
\hline (40) nii ìn buudèe Koofàa, & (40) I should open the door, \\
\hline (41) nii dà nakè gidan gàba. & (41) I who was in the passenger seat. \\
\hline (42) Na kaasà maa buudèe koofâa & (42) I couldn't even open the door \\
\hline (43) sabòo dà naa giggìcee, & (43) because I had panicked, \\
\hline (44) duk naa zàtaa & (44) I assumed \\
\hline (45) duk sun rìgaa sun mutù. & (45) they had all already died. \\
\hline (46) Na buudèe, & (46) I opened (it), \\
\hline (47) mukà yi saurii dà kyar̃ dai, & $\begin{array}{l}\text { (47) we moved quickly with real } \\
\text { difficulty, }\end{array}$ \\
\hline $\begin{array}{l}\text { (48) sai wani maalàmii ya buudèe mîn } \\
\text { koofâa, }\end{array}$ & $\begin{array}{l}\text { (48) then a teacher opened the door for } \\
\text { me, }\end{array}$ \\
\hline (49) mukà yi saurii, & (49) we moved fast, \\
\hline (50) mukà jee, & (50) we went, \\
\hline (51) mukà buuđèe, & (51) we opened (it), \\
\hline (52) mù jee & (52) to go \\
\hline (53) mù duubà & (53) and see \\
\hline
\end{tabular}




\begin{tabular}{|l|l|}
\hline $\begin{array}{l}\text { (54) mèe ya fàaru. } \\
\text { (55) Àshee lookàcîn dà sukà faadàa } \\
\text { raamin, }\end{array}$ & $\begin{array}{l}(54) \text { what had happened. } \\
\text { ditch, }\end{array}$ \\
\hline $\begin{array}{l}\text { (56) sai sukà faadàa cikin tà6oo, } \\
\text { (57) sai mootàa ta kafèe, }\end{array}$ & $(56)$ then they landed in some mud, \\
\hline (58) bà tà juuyàa ba. & $(57)$ then the car got stuck, \\
\hline (59) Shiikèenan mukà jee, & $(58)$ and didn't roll over. \\
\hline (60) kàafin mù jee maa, & $(59)$ That was that we went over, \\
\hline (61) sun faarà fitôowaa, & $(60)$ before we even went (to them), \\
\hline (62) duk gàbaa daya sukà fitoo. & $(61)$ they had started to get out, \\
\hline (63) Allàah ya kiyàayee, & $(62)$ and they all got out together. \\
\hline (64) bâa wandà ya yi ràunii. & $(63)$ God protected them, \\
\hline (65) Shiikèenan mukà jee, & $(64)$ no one was injured. \\
\hline (66) mukà tsai dà wasu mootoocii, & $(65)$ That was that we went, \\
\hline (67) mukà taimàkaa, & $(66)$ and we stopped some cars, \\
\hline (68) akà dagà mootàa, & $(67)$ and we helped out, \\
\hline (69) akà fitoo dà ita. & $(68)$ the car was lifted up, \\
\hline (70) Mukà yi kòokarii, & $(69)$ and it was pulled out. \\
\hline (71) dà mukà jaawoo tà, & $(70)$ We made an effort, \\
\hline (72) mukà canjà tayàa, & $(71)$ when we had pulled it out, \\
\hline (73) mukà daawoo gidaa laafiyàa. & $(72)$ we changed the tyre, \\
\hline
\end{tabular}

\section{APPENDIX B: The Pear Film Narrative}

(Note: Single underlining, e.g., ya, indicates (affirmative) Narrative/Focus Perfective; broken underlining, e.g., yaạ, indicates General Perfective.)

\begin{tabular}{|c|c|}
\hline (1) Dà farkoo dai wani mùtûm nee, & (1) First of all actually there's a man, \\
\hline (2) ya jee... & (2) he went \\
\hline (3) yanàa tsìnkar̃ mangwàrònshì. & (3) he's picking his mangoes. \\
\hline (4) Yanàa dà kwandunàa gùdaa ukù. & (4) He has three baskets. \\
\hline $\begin{array}{l}\text { (5) Shiikèenan, yaạ cikà kwàndoo gùdaa } \\
\text { biyu, }\end{array}$ & (5) OK, he had filled two baskets, \\
\hline (6) yạa hau kân mangwàrò̀n, & $\begin{array}{l}\text { (6) he had climbed to the top of the mango } \\
\text { tree, }\end{array}$ \\
\hline (7) zâi jee, & (7) he was about to go, \\
\hline (8) don yà tsinkoo mangwàròn & (8) to pick the mangoes \\
\hline $\begin{array}{l}\text { (9) dà zâi cikà kwàndonshì na kàrshee, } \\
\text { shii kwàndoo na ukù. }\end{array}$ & $\begin{array}{l}\text { (9) that he would fill his last basket with, } \\
\text { the third basket. }\end{array}$ \\
\hline (10) Yaa hau can, & (10) He had climbed up there, \\
\hline
\end{tabular}




\begin{tabular}{|c|c|}
\hline (11) yanàa kòokarin & (11) he was trying \\
\hline (12 yà tsittsinkoo, & (12) to pick (them), \\
\hline (13) sai wani yaaròo ya zoo à kân kèekè, & (13) then a boy came on a bike, \\
\hline (14) sai ya duubà mùtumìn. & (14) then he looked at the man. \\
\hline (15) Dà ya ga & (15) When he had seen \\
\hline (16) mùtumìn baa yàa kallonshì & (16) the man wasn't watching him, \\
\hline (17) sai ya dâukee kwàndôn. & (17) then he took the basket. \\
\hline (18) Dà ya dâukee kwàndoo daya & (18) When he had taken the one basket \\
\hline (19) wandà ya cikàa, & (19) that he had filled, \\
\hline (20) sai ya dooràa à kân kàar̃iyàr̃à, & (20) then he put it on his bike-rack, \\
\hline (21) sai ya fita à gùje. & (21) then he left in a hurry. \\
\hline (22) Yanàa ta gudùu à kân kèekènshì, & (22) He was speeding off on his bike, \\
\hline (23) yanàa ta gudùu à kân kèekènshì. & (23) he was speeding off on his bike. \\
\hline $\begin{array}{l}\text { (24) Can à kân hanyàa sai kuma gàa wata } \\
\text { yaarinyàa, }\end{array}$ & (24) And then there on the road was a girl, \\
\hline (25) taa tahoo dàgà wani gurii. & (25) she had appeared from somewhere. \\
\hline (26) Lookàcîn dà sukà zoo & (26) When they had arrived \\
\hline (27) zaa sù giftàa. & (27) they were about to pass by. \\
\hline (28) Sunn giftà juunaa, & (28) They had passed each other, \\
\hline (29) yanàa can & (29) he was there, \\
\hline (30) yanàa kallon yaarinyàr̃ , & (30) he was watching the girl \\
\hline (31) sai ya yi karòo dà duutsèe, & (31) then he bumped into a rock, \\
\hline (32) sai ya faadî dà kèekèn, & (32) then he fell down with the bike, \\
\hline (33) duk sai mangwàr̃òn ya zubèe. & (33) then the mangoes spilled all out. \\
\hline (34) Shiikèenan sai ya yi saa'àa, & (34) OK then he was lucky, \\
\hline (35) gàa wasu yâaraa, & (35) there were some boys, \\
\hline (36) sun zoo daidai gurîn, & (36) they had come right to the place, \\
\hline (37) sunàa wàasaa, & (37) they were playing. \\
\hline (38) Sai yâarân sukà zoo, & (38) Then the boys came, \\
\hline (39) sukà tàimàkee shì & (39) they helped him \\
\hline (40) yà tsìntsìnci mangwàròòn, & (40) to pick up the mangoes, \\
\hline (41) nii dà nakè gidan gàba. & $\begin{array}{l}\text { (41) they collected them for him in the } \\
\text { basket. }\end{array}$ \\
\hline (42) Shiikèenan, sai ya hau kân... & (42) That was that, then he climbed on... \\
\hline (43) ya faarà tuurà kèekènshì, & (43) he started to push his bike, \\
\hline (44) ya yi tàfiyàr̃shì. & (44) he went on his way. \\
\hline (45) Tôo, àshee yaa bar̃ hùular̃à & (45) OK, but he had left his hat \\
\hline (46) à wurîn dà akà yi karòn, & (46) at the place where he had crashed, \\
\hline (47) sai wani yaaròo sai ya ga hùulâr. & (47) then a boy saw the hat. \\
\hline
\end{tabular}




\begin{tabular}{|l|l|}
\hline (48) Sai ya koomàa mishì dà ita, & $(48)$ Then he returned it to him, \\
\hline (49) ya jee, & $(49)$ he went, \\
\hline (50) ya baa shì, & $(50)$ he gave it to him, \\
\hline (51) ya cèe gàa hùular̃shì. & $(51)$ he said here is his hat. \\
\hline $\begin{array}{l}\text { (52) Shiikèenan, dà ya baa shì hùulâr̃, } \\
\text { mangwàrò gùdaa ukù, }\end{array}$ & $(52)$ OK, when he had given him the hat, \\
\hline (54) dâa maa yâarân suu ukù nee & $(53)$ then the boy took three mangoes, \\
\hline (55) sai ya baa sù & $(54)$ all along there were three boys, \\
\hline (56) sù jee & $(55)$ then he gave them (the mangoes) \\
\hline (57) sù shaa. & $(56)$ to go \\
\hline (58) Yâarân sunn kàrbi mangwàròn, & $(57)$ and eat. \\
\hline (59) sunàa tàfiyàa can, & $(58)$ The boys had taken the mangoes, \\
\hline $\begin{array}{l}\text { (60) sai sukà bi ta hanyàr mài mangwàròn } \\
\text { nan. }\end{array}$ & $\begin{array}{l}(69) \text { they were going off, } \\
\text { mango-man. they followed the road of that }\end{array}$ \\
\hline (61) A'a shii kuma à lookàcîn yạa saukoo & $\begin{array}{l}(61) \text { Well he had climbed down at the } \\
\text { time, }\end{array}$ \\
\hline (62) yanàa duubàa & $(62)$ he was looking \\
\hline (63) ìnaa kwàndonsà daya ya faadî, & $(63)$ where his one basket had fallen, \\
\hline (64) sai ya ga & $(64)$ then he saw \\
\hline (65) yâaraa kawài sunn ficèe, & $(65)$ the boys had just passed by, \\
\hline (66) sunàa shân mangwàrò. & $(66)$ they were eating the mangoes. \\
\hline (67) Sai ya tsayàa, & $(67)$ Then he stopped, \\
\hline (68) yanàa tùnàanin & $(68)$ he was thinking \\
\hline (69) a'a, yàayàa akà yi & $(69)$ hey, how had it happened \\
\hline (70) yâarân nan sukà sàami mangwàròn? & $(70)$ those boys had got the mangoes? \\
\hline (71) Kàrshen làabaar̃ii kèenan. & $(71)$ That's the end of the story. \\
\hline
\end{tabular}

\section{REFERENCES}

Abraham, R. C. 1959. The Language of the Hausa People. London: University of London Press.

Anderson, Stephen C. 1979. "Verb structure.” In Aghem Grammatical Structure, ed. by Larry M. Hyman, pp. 73-136. (Southern California Occasional Papers in Linguistics , 7).

Bagari, Dauda M. 1976. Subordinate Adverbial Clauses in Hausa. Ph.D. dissertation, UCLA. 
1987. Hausa Subordinate Adverbial Clauses: Syntax and Semantics. Rabat [Morocco]: El Maarif Al Jadida.

Bearth, Thomas. 1993. "Satztyp und Situation in einigen Sprachen Westafrikas." In Beiträge zur afrikanischen Sprach- und Literatur-wissenschaft, ed. by W. J. G. Möhlig, S. Brauner, and H. Jungraithmayr, pp. 91-104. Cologne: Köppe.

Biber, Douglas. 1984. "Pragmatic roles in Central Somali discourse." Studies in African Linguistics 15:1-26.

Burquest, Donald A. (ed.). 1991. Special section on Hausa narrative structure. Journal of West African Languages 21(2):41-117.

. 1992. "An introduction to the use of aspect in Hausa narrative." In Language in Context: Essays for Robert E. Longacre, ed. by Shin Ja J. Hwang and William R. Merrifield, pp. 393-417. Dallas: SIL and University of Texas at Arlington.

Caron, Bernard. 1991. Le haoussa de l'Ader. Berlin: Dietrich Reimer.

. 2000. "Assertion et préconstruit: Topicalisation et focalisation dans les langues africaines." In Topicalisation et focalisation dans les langues africaines, ed. by Bernard Caron, pp. 7-42. Louvain: Peeters.

Chafe, Wallace L. (ed.). 1980. The Pear Stories: Cognitive, Cultural, and Linguistic Aspects of Narrative Production. Norwood, N.J.: Ablex.

Comrie, Bernard. 1976. Aspect: An Introduction to the Study of Verbal Aspect and Related Problems. Cambridge: Cambridge University Press.

. 1985. Tense. Cambridge: Cambridge University Press.

Creissels, Denis. 1991. Description des langues négro-africaines et théorie syntaxique. Grenoble: Ellug.

Declerck, Renaat. 1986. "From Reichenbach (1947) to Comrie (1985) and beyond." Lingua 70:305-64.

. 1991. Tense in English: Its Structure and Use in Discourse. London: Routledge.

Dorfman, Eugene. 1969. The Narreme in the Medieval Romance Epic. Toronto: University of Toronto Press.

Galadanci, M. K. M. 1976. An Introduction to Hausa Grammar. Ikeja: Longman.

Gouffé, Claude. 1963/66. "Les problèmes de l'aspect en haoussa. I - Introduction. Le problème de l'aoriste et de l'accompli II." Comptes rendus du groupe linguistique d'études chamito-sémitiques [GLECS] 10:151-65.

Green, Melanie. 1997. Focus and Copular Constructions in Hausa. Ph.D. dissertation, University of London. (To appear in: Publications of the Philological Society Series, Oxford: Blackwell.)

Green, Melanie, and Chris H. Reintges. 2005. "Syntactic conditions on special inflection: Evidence from Hausa and Coptic Egyptian interrogative and focus 
constructions." University of Sussex Working Papers in Linguistics and English Language (LxWP14/05).

Grimes, Joseph E. 1975. The Thread of Discourse. The Hague: Mouton.

Hartmann, Katharina. In press. "Focus constructions in Hausa." In The Architecture of Focus. Studies in Generative Grammar, ed. by Valéria Molnár and Susanne Winkler. Berlin: Mouton de Gruyter.

Hartmann, Katharina, and Malte Zimmermann. In press. "In place - out of place: Focus in Hausa." In Proceedings of the Workshop on Information Structure and the Architecture of Grammar, ed. by Kerstin Schwabe and Susanne Winkler. Amsterdam: John Benjamins.

Hopper, Paul J. 1979. "Aspect and foregrounding in discourse." In Discourse and Syntax: Syntax and Semantics vol. 12, ed. by Talmy Givón, pp. 213-41. New York: Academic Press.

(ed.). 1982. Tense-Aspect: Between Semantics and Pragmatics. Amsterdam: John Benjamins.

Hopper, Paul J., and Sandra A. Thompson. 1980. "Transitivity in grammar and discourse." Language 56:251-99.

Huddleston, Rodney, and Geoffrey K. Pullum. 2002. The Cambridge Grammar of the English Language. Cambridge: Cambridge University Press.

Hyman, Larry M., and John R. Watters. 1984. "Auxiliary focus.” Studies in African Linguistics 15:233-73.

Jaggar, Philip J. 1998. "Restrictive vs. non-restrictive relative clauses in Hausa: Where morphosyntax and semantics meet." Studies in African Linguistics 27:199-238.

. 2001. Hausa. (London Oriental and African Language Library, 7). Amsterdam: John Benjamins.

Jungraithmayr, Herrmann, and Muhammad Munkaila. 1985. "On the sun-set in Hausa." Africana Marburgensia 18:63-71.

Labov, William. 1972. "The transformation of experience in narrative syntax." In Language in the Inner City, ed. by William Labov, pp. 354-96. Philadelphia: University of Pennsylvania Press.

Longacre, Robert E. 1990. Storyline Concerns and Word Order Typology in East and West Africa. (Studies in African Linguistics, Supplement 10). Los Angeles: African Studies Center, UCLA.

Matthiessen, Christian, and Sandra A. Thompson. 1988. "The structure of discourse and 'subordination'." In Clause Combining in Grammar and Discourse, ed. by John Haiman and Sandra A. Thompson, pp. 275-329. Philadelphia: Benjamins. 
Newman, Paul. 1974. The Kanakuru Language. (West African Language Monographs, 9). Leeds: Institute of Modern English Language Studies, University of Leeds and West African Linguistic Society.

. 2000. The Hausa Language: An Encyclopedic Reference Grammar. New Haven: Yale University Press.

Newman, Paul, and Russell G. Schuh. 1974. "The Hausa aspect system." Afroasiatic Linguistics 1:1-39. Los Angeles: Undena Publications.

Parsons, F. W. 1960. "The verbal system in Hausa.” Afrika und Übersee 44:1-36.

Quirk, Randolph, Sidney Greenbaum, Geoffrey Leech, and Jan Svartvik. 1985. A Comprehensive Grammar of the English Language. London: Longman.

Reinhart, Tania. 1984. "Principles of gestalt perception in the temporal organization of narrative texts." Linguistics 22:779-809.

Schachter, Paul. 1973. "Focus and relativization." Language 49:19-46.

Schubert, Klaus. 1971-72. "Zur Bedeutung und Anwendung der Verbalparadigmen im Hausa und Kanuri." Afrika und Übersee 55:1-49, 208-27, 267-300; 56: 90118.

Schuh, Russell G. 1977. "West Chadic verb classes." In Papers in Chadic Linguistics, ed. by Paul Newman and Roxana Ma Newman, pp. 143-66. Leiden: Afrika-Studiecentrum.

. 2003. "The functional unity of the Hausa and West Chadic subjunctive." UCLA Working Papers in Linguistics, 9 (Papers in African Linguistics, 3).

. n.d.a. "Hausa tense/aspect/mood (TAM) system." Unpublished ms, Department of Linguistics, UCLA.

. n.d.b. "Ma'anonin hange cikakke na Hausa" [The meanings of the perfective tense in Hausa]. Unpublished ms, Department of Linguistics, UCLA.

. n.d.c. "On the origin of the Hausa 'relative' aspects and the 'stabilizer'." Unpublished ms, Department of Linguistics, UCLA.

Tuller, Laurice A. 1986. Bijective Relations in Universal Grammar and the Syntax of Hausa. Ph.D. dissertation, UCLA.

Wolff, Ekkehard. 1993. Referenzgrammatik des Hausa. (Hamburger Beiträge zur Afrikanistik, 2). Münster \& Hamburg: Lit.

Philip J. Jaggar

SOAS, University of London

email: pj@soas.ac.uk 